\title{
TINDAKAN PENANGANAN DIARE PADA ANAK DI DESA PADANG MUTUNG KECAMATAN
}

\author{
Rahma Dini Lestari $^{1}$, Nila Kusumawati ${ }^{2}$, Putri Eka Sudiarti ${ }^{3}$ \\ Prodi S1 Keperawatan Universitas Pahlawan Tuanku Tambusai \\ rahmadinilestari07@gmail.com ${ }^{1}$, nilakusumawatielison1@ gmail.com²
}

\begin{abstract}
The World Health Organization states that about $20 \%$ of children die from diarrhea each year. The first action a mother takes on a child suffering from diarrhea will determine the patient's condition. This study aims to determine the actions of mothers in dealing with diarrhea in children in Padang Mutung Village, Kampar District, Kampar Regency. This type of research is a qualitative narrative descriptive approach. The sampling technique was purposive sampling as many as 15 respondents. Collecting data by interview and using a list of questions about the reasons mothers do not bring their children with diarrhea to health services and the actions taken by mothers at home to overcome diarrhea in their children. The results of the analysis were obtained from processing data on 15 respondents using three lines of qualitative data analysis, namely data reduction, presenting data, and drawing conclusions. Based on this study, it was found that the reasons for mothers not bringing their children to health services were because of the perceptions of mothers that diarrhea did not endanger their children and saved costs. Actions taken by the mother at home were giving ORS, bitter tea, milk, steamed rice, food stalls such as tetra and entrostop. Mothers prefer to take action at home to treat diarrhea in their children by using various village remedies. It is hoped that the Puskesmas will conduct socialization on the importance of bringing children with diarrhea to health services.services.
\end{abstract}

Keywords $\quad$ : Action, Children, Diarrhea, Mother

\begin{abstract}
ABSTRAK
World Health Organization mengungkapkan bahwa sekitar 20\% anak meninggal karena diare setiap tahunnya. Tindakan pertama yang dilakukan ibu pada anaknya yang menderita diare sangat menentukan kondisi pasien. Penelitian ini bertujuan untuk mengetahui tindakan ibu - ibu dalam menangani diare pada anak di Desa Padang Mutung Kecamatan Kampar Kabupaten Kampar. Jenis penelitian yang digunakan adalah kualitatif pendekatan deskriftif naratif. Teknik pengambilan sampelpada penelitian menggunakana teknik purposive sampling yaitu sebanyak 15 responden. Pengumpulan data dengan wawancara dan menggunakan daftar pertanyaan tentang alasan ibu tidak membawa anak yang menderita diare ke pelayanan kesehatan dan tindakan yang dilakukan ibu dirumah untuk mengatasi diare pada anaknya. Hasil analisis yang diperoleh dari pengolahan data kepada 15 responden dengan menggunakan tiga jalur analisis data kulaitatif yaitu reduksi data, menyajikan data, dan menarik kesimpulan. Berdasarkan penelitian ini didapatkan alasan ibu tidak membawa anaknya ke pelayanan kesehatan karena persepsi ibu bahwa diare tidak membahayakan anaknya dan menghemat biaya. Tindakan yang dilakukan ibu dirumah adalah pemberian oralit, teh pahit, susu, beras direndang, obat warung seperti sepertetra dan entrostop. Ibu lebih memilih melakukan tindakan dirumah untuk mengatasi diare pada anaknya dengan berbagai macam cara pengobatan kampung. Diharapkan kepada Puskesmas untuk melakukan sosialisasi tentang pentingnya membawa anak yang diare ke pelayanan kesehatan.
\end{abstract}

Kata kunci : Anak, Diare, Ibu, Tindakan

\section{PENDAHULUAN}

Penyakit diare sering timbul dalam bentuk kejadian luar biasa dan disertai dengan kematian yang tinggi di negara berkembang seperti di Indonesia. Diare juga merupakan penyakit kedua tertinggi yang 
menyebabkan kematian pada anak - anak (Kemenkes RI, 2011).

Menurut World Health Organization (WHO) sekitar 780.000 anak balita meninggal akibat diare setiap tahunnya. Di kawasan Afrika dan Asia Tenggara telah mencapai angka sebesar $78 \%$ dari total jumlah kejadian diare di dunia (Sari et al, 2017). Data Profil Kesehatan Indonesia pada tahun 2015 jumlah kasus diare adalah 213.435 penderita dengan jumlah kematian 1.289 orang (Kemenkes RI, 2015). Sedangkan prevalensi kejadian diare pada anak di Provinsi Riau tahun 2015 berkisar sekitar 5,2\%. Pada Provinsi Riau kasus diare tertinggi kedua yaitu Kabupaten Kampar sebanyak 16.128 orang. Angka kejadian diare pada anak di Kabupaten Kampar pada tahun 2019 yaitu 15.046 orang dimana yang mendapat oralit sebanyak 393 orang. Salah satu puskesmas yang memiliki jumlah anak dengan diare yang tinggi adalah Puskesmas Kampar dengan 892 jiwa. Desa Padang Mutung adalah Desa yang memiliki jumlah anak mengalami diare yang tertinggi yaitu 157 orang.

Diare dapat disebabkan oleh beberapa factor yaitu status gizi, Air Susu Ibu (ASI) eksklusif, pengetahuan ibu, ketersedian sumber air bersih, ketersediaan jamban keluarga, lingkungan, pola hidup, kebiasaan mencuci tangan, perilaku makan, imunisasi dan sosial ekonomi. Penyebab langsung antara lain infeksi bakteri virus dan parasit, malabsorbsi, alergi, keracunan bahan kimia maupun keracunan oleh racun yang diproduksi oleh jasad renik, ikan, buah dan sayur - sayuran (Maidartati et al, 2017 ; Zaitun, 2011).

Anak yang mengalami diare akan mengakibatkan kekurangan cairan terus menerus sehingga dapat mengakibatkan dehidrasi. Diare juga dapat mengakibatkan malnutrisi (Depkes RI, 2010). Diare yang tidak segera ditangani dapat menyebabkan hipoglikemia bahkan kematian Sehingga anak yang diare harus segera mendapatkan penanganan dengan membawa ke pelayanan kesehatan terdekat (Nugroho, 2018). Jika anak yang mengalami diare tidak segera dibawa ke pelayanan kesehatan maka anak akan mengalami gangguan keseimbangan asam basa (metabolik asidosis), hipoglikemia, penurunan berat badan dan gangguan sirkulasi darah. Anak diare yang mendapat pengangan di pelayanan kesehatan lebih awal dapat mencegah komplikasi (Maryunani, 2010).

Survei awal yang dilakukan peneliti terhadap 20 orang ibu di Desa Padang Mutung Kecamatan Kampar Kabupaten Kampar yang anaknya menderita diare ditujukan untuk menggali informasi tindakan yang dilakukan ibu ketika anaknya mengalami diare adalah sebagai berikut : enam orang ibu mengatakan membawa anaknya yang menderita diare ke pelayanan kesehatan dan empat belas orang mengatakan tidak membawa anaknya ke pelayanan kesehatan apabila anaknya menderita diare.

Dalam penelitian ini peneliti bertujuan melakukan penelitian tentang tindakan ibu ibu di Desa Padang Mutung Kecamatan Kampar Kabupaten Kampar dalam menangani diare pada anaknya sebelum dibawa ke fasilitas kesehatan/pelayanan kesehatan.

\section{METODE}

Jenis penelitian ini adalah penelitian deskriptif melalui pendekatan penelitian kualitatif, dengan menggunakan pendekatan deskriptif naratif. Penelitian ini dilakukan pada tanggal 21 Juni - 02 Juli tahun 2020 di Desa Padang Mutung Kecamatan Kampar Kabupaten Kampar Tahun 2019. Populasi penelitian ini adalah ibu - ibu yang memiliki anak yang menderita diare minimal 1 bulan sebelum penelitian dilakukan, ibu dengan anak usia 6-10 tahun di Desa Padang Mutung Kecamatan Kampar Kabupaten Kampar. Sampel penelitian ini adalah ibu yang anaknya menderita diare sebanyak 15 orang dengan teknik purposive samping. Penelitian akan dihentikan bila saturasi data telah tercapai. 
Variabel penelitian ini adalah Alat pengumpulan data adalah lembar pertanyaan wawancara yang terdiri dari empat pertanyaan yang dibuat sendiri oleh peneliti dan alat perekam suara (recorder)dan foto menggunakan hanphone (HP), buku tulis, pena dan masker. Teknik pengumpulan data dilakukan dengan Indepth Interview. Analisa data penelitian menggunakan Tematik Analisis. Analisa data dilakukan dengan tiga jalur yaitu: reduksi data, penyajian data dan menarik kesimpulan.

\section{HASIL}

\section{Karakteristik Responden}

Jumlah informan seluruhnya terdiri dari 15 orang ibu dengan anak usia sekolah yang pernah menderita diare dalam satu bulan terakhir.

Tabel 1. Karakteristik Responden Desa Padang Mutung Wilayah Kerja Puskesmas Kampar Tahun 2020

\begin{tabular}{lccccc}
\hline Responden & \multicolumn{5}{c}{ Karakteristik Responden } \\
\cline { 2 - 6 } & $\begin{array}{c}\text { Usia Ibu } \\
\text { (tahun) }\end{array}$ & $\begin{array}{c}\text { Usia Anak } \\
\text { (tahun) }\end{array}$ & Pendidikan & Pekerjaan & Jumlah Anak \\
\hline R1 & 25 & 9 & SD & Wirausaha & 3 \\
R2 & 40 & 10 & SMA & IRT & 6 \\
R3 & 34 & 9 & SD & IRT & 2 \\
R4 & 48 & 8 & SD & Wirausaha & 6 \\
R5 & 39 & 8 & SD & IRT & 3 \\
R6 & 36 & 7 & SMP & IRT & 2 \\
R7 & 30 & 6 & SMP & IRT & 2 \\
R8 & 26 & 8 & SMA & IRT & 2 \\
R9 & 29 & 10 & SMA & IRT & 2 \\
R10 & 30 & 8 & SMP & Petani & 5 \\
R11 & 35 & 10 & SMP & IRT & 3 \\
R12 & 37 & 9 & SD & IRT & 4 \\
R13 & 45 & 8 & SD & IRT & 2 \\
R14 & 39 & 10 & SD & IRT & 4 \\
R15 & 33 & 9 & SMP & IRT & 3 \\
\hline
\end{tabular}

Usia informan ibu dengan anak usia sekolah (6 - 10 tahun) penderita diare adalah 23 tahun sampai 48 tahun. Pendidikan ibu dengan anak penderita diare terdiri dari SD, SMP dan SMA. Sedangkan pekerjaan ibu adala IRT, Petani dan Wirausaha.

\section{Alasan Ibu Tidak Langsung Membawa Anak Diare ke Pelayanan Kesehatan}

Persepsi ibu - ibu tentang diare

Ibu berpersepsi kalau penyakit diare tidak membahayakan bagi anak sehingga menggunakan obat kampung untuk tindakan pertama lebih baik dilakukan di rumah terlebih dahulu. Apabila diare pada anak tidak teratasi dengan tindakan yang dilakukan di rumah baru anaknya dibawa ke pelayanan kesehatan.

"...Allhamdulilah selama ini masih manjur, kalau masih manjur cukup dengan pemberian obat tradisional di rumah kalau tidak manjur baru saya bawa ke pelayanan kesehatan (Ds, 26 tahun, anak usia sekolah usia 8 tahun).

Penghematan Biaya

Ibu - ibu juga mengatakan bahwa alasan yang lain adalah agar lebih menghemat biaya.

“...Itu dulu saya coba kalau tidak memungkinkan sembuh (berlarut - larut) sakit mencret tersebut baru dibawa ke pelayanan kesehatan, itu untuk menghemat biaya" (Hd, 45 tahun, anak usia sekolah usia 8 tahun). 
Tindakan yang Ibu Lakukan di rumah Untuk Mengatasi Diare Pada Anak di rumah

\section{Pemberian Oralit}

Sebagian ibu memberikan pertolongan pertama dengan pemberian oralit buatan sendiri yaitu air dengan campuran gula dan garam. Pemberian oralit diberikan oleh 4 dari 15 orang ibu.

“...Biasa kalau apa ya oralit, garam dilarutkan dengan air"'(An, 25 tahun, anak usia sekolah usia 9 tahun).

\section{Pemberian Pucuk Daun Jambu Biji}

Sebagian ibu memberikan pertolongan pertama dengan pemberian daun pucuk daun jambu biji sebagai tindakan dirumah untuk mengatasi anaknya yang mengalami diare. Pemberian daun jambu ini juga bermacam-macam, yaitu dengan cara di kunyah-kunyah oleh anaknya yang terserang diare,dan adapula yang memasak daun jambu dengan air kemudian airnya diminum dan ada juga daun jambu biji ditumbuk baru disuruh makan pada anak yang menderita diare. Pemberian pucuk daun jambu biji dilakukan oleh 10 dari 15 orang ibu.

"...Pucuk daun jambu direbus, dikasih airnya”. (Pn, 48 tahun, anak usia sekolah usia 8 tahun)

\section{Pemberian Teh Pahit}

Sebagian ibu memberikan pertolongan pertama dengan pemberian teh pahit dicampur garam. Pemberian teh pahit diberikan oleh 1 dari 15 orang ibu.

"...Pertama saya cari obat alami dulu seperti teh pahit campur garam sedikit" (Nn, 39 tahun, anak usia sekolah usia 8 tahun).

\section{Pemberian Beras Rendang}

Sebagian ibu memberikan pertolongan pertama dengan pemberian beras rendang. Pemberian beras rendang diberikan oleh 1 dari 15 orang ibu.

“...Kalau saya apa yang saya berikan hmm rendang beras tu habis tu kalau sudah sedikit dingin disiram dengan air kemudian airnya diminum dan beras yang hangus tadi dimakan juga" (Hd, 45 tahun, anak usia sekolah usia 8 tahun).

\section{Pemberian Susu}

Sebagian ibu memberikan pertolongan pertama dengan pemberian susu. Pemberian susu diberikan oleh satu dari 15 orang ibu.

“...Saya berikan susu” (As, 36 tahun, anak usia sekolah usia 7 tahun).

\section{Pemberian Obat Warung}

Sebagian ibu memberikan pertolongan pertama dengan pemberian obat warung seperti tetra dan enterstop. Pemberian obat warung diberikan oleh 2 dari 15 orang ibu.

"...Saya berikan obat warung seperti supetetra” (Ms, 34 tahun, anak usia sekolah usia 9 tahun).

\section{PEMBAHASAN}

Berdasarkan hasil penelitian ini dipaparkan bahwa ibu - ibu di Desa Padang Mutung Wilayah Kerja Puskesmas Kampar mempunyai kebiasaan melakukan pengobatan sendiri bila anaknya mengalami diare. Namun, bila keadaan belum baik atau belum stabil informan membawa anaknya ke puskesmas.

Hasil pengamatan peneliti pemberian oralit terhadap penanganan anak yang mengalami diare sudah dipercaya sejak lama. Oralit juga ada dijual diapotik, akan tetapi ibu - ibu lebih memilih membuat oralit sendiri dirumah agar lebih menghemat biaya. Hasil penelitian ini sesuai dengan penelitian yang dilakukan oleh Nugroho (2018) pemberian oralit dapat membantu mengatasi diare pda anak. Oralit dipercaya dapat mengatasi diare pada anak karena kandungan garam (natrium klorida) dan glukosa dalam oralit. Menurut Indriyani (2017) kandungan glukosa pada oralit membantu meningkatkan reabsorpsi air dan elektrolit yang tersekresi ke lumen usus saat diare. Hal ini dapat terjadi karena terdapat 
mekanisme ko-transpor antara natrium dan glukosa. Proses reseptor ion natrium dan glukosa bekerja sama dalam membantu meningkatkan reabsorpsi ion natrium dari dalam lumen usus menuju sel plasma yang dapat mengurangi kadar ion natrium di dalam lumen usus. Proses ini dapat meningkatkan fungsi absorbsi cairan oleh mukosa usus sehingga mengurangi kadar air dalam lumen usus yang menghasilkan perbaikan pada konsistensi feses pada kejadian diare.

Hasil pengamatan peneliti tanaman tradisional yang sering digunakan untuk mengatasi diare adalah pemberian pucuk daun jambu biji. Hasil penelitian ini didukung juga oleh penelitian yang dilakukan oleh Ningsih (2014) yang mengatakan pertolongan pertama ibu pada anaknya yang menderita diare adalah pemberian daun jambu biji dimasak dan dikunyah. Menurut Adnyana (2014) kandungan astringent dalam jambu biji bersifat alkali dan memiliki kemampuan desinfektan serta anti bakteri, sehingga membantu penyembuan infeksi diare. Nutrisi lain daun jambu biji seperti kalium, vitamin C dan karotenoid melemahkan sistem pencernaan bakteri penyebab diare, yaitu staphylococcus aureus dan E. coli.

Hasil pengamatan peneliti tindakan yang dilakukan ibu untuk mengatasi diare pada anaknya adalah pemberian teh pahit. Hasil penelitian ini sesuai dengan penelitian yang dilakukan oleh Setiawan (2012) menunjukkan pemberian teh pahit dapat mengatasi diare pada anak. Kandungan tanin di dalam teh akan memberikan efek astringen berupa mengurangi frekuensi diare serta membatasi kandungan air di dalam feses.

Berdasarkan hasil penelitian ini maka peneliti berasumsi bahwa responden lebih memilih tidak membawa anaknya berobat ke pelayanan kesehatan karena ibu - ibu beranggapan penyakit diare merupakan penyakit yang biasa diderita setiap orang termasuk anak - anak. Tindakan ibu berbeda-beda dalam menangani anaknya yang diare sesuai dengan pemahaman yang ibu miliki serta lingkungan yang mempengaruhi. Ibu yang memilih merawat anaknya dirumah. Apabila diare yang diderita anaknya tidak sembuh baru dibawa ke pelayanan kesehatan dengan alasan mengemat biaya pembelian obat di tenaga kesehatan. Tindakan yang diberikan kebanyakan obat tradisional yaitu pembuatan oralit, teh pahit dan obat tanaman tradisional seperi daun jambu biji yang sudah dipercaya secara turun- temurun dan ampuh menyembuhkan penyakit diare.

\section{KESIMPULAN}

Alasan ibu tidak langsung membawa anak yang diare ke pelayanan kesehatan di Desa Padang Mutung Kecamatan Kampar Kabupaten Kampar yaitu terbiasa menggunakan obat tradisional apabila anaknya menderita diare dan penyakit diare tidak mengancam nyawa penderita diare

Tindakan yang ibu lakukan dirumah untuk mengatasi diare pada anak dirumah yaitu pembuatan oralit dirumah, teh pahit campur garam, air hangat, susu, daun pucuk jambu biji dan obat warung seperti supetetra dan entrostop.

\section{DAFTAR PUSTAKA}

Adnyana IK, Yulinah E, Sigit JI, Insanu M. (2014). Efek Ekstrak Daun Jambu Biji Daging Buah Putih dan Jambu Biji Daging Buah Merah sebagai Antidiare. Acta Pharmaceutica Indonesia, Volume 29, Nomor (1) : 19-27.

Depkes RI. (2010). Situasi Diare di Indonesia:Subdit Pengendalian Diare dan Infeksi Saluran Pencernaan. Depkes RI. Jakarta.

Indriani RA. (2014). Analisis Pelaksanaan Program Diare Di Puskesmas Medan Deli Kecamatan Medan Deli Tahun 2014. Skripsi. Fakultas Kesehatan Masyarakat Universitas Sumatera Utara Medan. 
Kemenkes RI. (2011). Standar Antropometri Penilaian Status Gizi Anak. Keputusan Menteri Kesehatan Republik Indonesia. Jakarta. (2015). Profil Kesehatan Indonesia 2015. Keputusan Menteri kesehatan Republik Indonesia. Jakarta.

Maidartati, Anggraeni RD. (2017) FaktorFaktor Yang Berhubungan Dengan Kejadian Diare Pada Balita (Studi Kasus : Puskesmas Babakansari). Jurnal Keperawatan BSI, Vol 5, No. 1.

Maryunani A. (2010). Ilmu Kesehatan Anak. Jakarta : CV. Trans Info Media.

Ningsih H, Syafar M, Nyorong M. (2014). Perilaku Ibu Terhadap Pencegahan Dan Pengobatan Balita Penderita Diare Di Wilayah Kerja Puskesmas
Belawa. Jurnal MKMI, Volume 1, Nomor (1) : 51-56.

Nugroho KD.(2018). Edukasi Dokter Pada Orangtua Dengan Bayi Diare Usia O6 Bulan Di Puskesmas Tegal Barat. Fakultas Kedokteran, Universitas Sebelas Maret Surakarta.

MH. (2017). Hubungan Perilaku Cuci Tangan Dengan Kejadian Diare Pada Balita di Posyandu Dusun Nglebeng Tamanan Banguntapan Bantul. Naskah Publikasi. Fakultas Ilmu Kesehatan Universitas 'Aisyiyah Yogyakarta.

Setiawati H. (2015). Pengaruh Pemberian Diet Bubur Tempe Terhadap Frekuensi Bab Pada Anak Diare Di Ruang Mina Rumah Sakit PKU Muhammadiyah Surakarta . Naskah Publikasi Ilmiah. Fakultas Ilmu Kesehatan, Universitas Muhammadiyah Surakarta. 